\author{
Sławomir Dorocki \\ Pawel Brzegowy \\ Uniwersytet Pedagogiczny \\ im. Komisji Edukacji Narodowej \\ w Krakowie
}

\title{
Intensyfikacja usług uzdrowiskowych w Polsce po okresie transformacji systemowej
}

\section{Intensification of spa services in Poland following the system transformation period}

\section{Streszczenie}

Intencją poniższego studium jest zaprezentowanie ogólnego charakteru przemian zaistniałych w polskich uzdrowiskach po 1989 r. W 2014 r. 44 miejscowości, bądź ich części, oraz Kopalnia Soli w Wieliczce miały status uzdrowiska, a największą koncentracją zdrojowisk charakteryzowało się województwo dolnośląskie. Odwołując się do danych statystycznych, raportów GUS i Ministerstwa Zdrowia oraz literatury przedmiotu i własnych obserwacji, zilustrowano stan infrastrukturalny wybranych zdrojowisk wraz z jego wykorzystaniem. Przez termin infrastruktura turystyczna autorzy rozumieją bazę noclegową z elementami lecznictwa uzdrowiskowego, zdefiniowanymi we właściwym ustawodawstwie. Szczególną uwagę poświęcono zagadnieniu działalności sanatoryjnej, badając zmianę liczby sanatoriów (najpowszechniejszego rodzaju placówek lecznictwa zdrojowiskowego) i szpitali uzdrowiskowych, począwszy od połowy lat 90 . ubiegłego wieku. W dalszej kolejności zobrazowano zmiany w liczebności kuracjuszy poszczególnych kurortów. Czy w związku z przemianami politycznymi, gospodarczymi i społecznymi, które dokonały się w okresie ostatniego ćwierćwiecza, w polskich uzdrowiskach nastąpiły zauważalne zmiany ilościowe i jakościowe? Które z nich najlepiej wykorzystały okres transformacji systemowej, stając się krajowymi liderami na rynku usług lecznictwa uzdrowiskowego?

\begin{abstract}
The intention behind this study is to present the general character of the changes affecting Polish spa resorts after 1989. In 2014, 44 localities (or parts thereof), and the Wieliczka salt mine, held the status of spa resorts while the Lower Silesian Voivodeship was characterised with the greatest concentration of spa facilities. Referring to the statistical data, reports published by GUS - the National Statistical Office and Ministry of Health, as well as the subject-related bibliography and their own in-situ observations, the authors illustrated the infrastructural condition of the selected spa resorts, and the use of the same. By the term "infrastructure" the authors understand an accommodation base combined with elements of spa treatment as defined in related legislation. Special attention was paid to sanatorium activities through analysing the changing number of sanatoriums (the most common type of spa treatment facility) and spa hospitals starting from the mid-1990s. Secondly, the changing number of patients visiting particular spa resorts was presented. Have any noticeable quantitive and qualitative changes occurred in Polish spa resorts in connection with the political, economic and social transformations taking place during the last quarter-century? Which of these spas benefitted best from the system transformation period, becoming leaders on the domestic spa market?
\end{abstract}

Slowa kluczowe: infrastruktura turystyczna; kuracjusze; transformacja systemowa; uzdrowiska Key terms: spa patients; spa resortssystem transformation; tourist infrastructure 


\section{Wstęp}

W Polsce od okresu transformacji gospodarczej następują intensywne zmiany, zauważalne zarówno w sferze gospodarczej, jak i społecznej. Ich bodźcem są wymogi dostosowania ekonomii narodowej do warunków gospodarki rynkowej oraz procesy globalizacyjne (Rachwał, 2006). Transformacje te nie ominęły sektora opieki zdrowotnej, w tym lecznictwa uzdrowiskowego. Obecnie, w wyniku procesu starzenia się społeczeństwa, rosnącej konkurencji na światowym rynku usług zdrowotnych oraz zmian w potrzebach kuracjuszy, a także dzięki rozwojowi medycyny, wydaje się, że to właśnie w uzdrowiskach od lat 90. XX w. nastąpiły jedne z najlepiej widocznych przeobrażeń polskiej transformacji gospodarczej (Wołowiec, 2002, 2003).

Celem pracy jest przedstawienie zmian, które zaszły w polskich zdrojowiskach od połowy lat 90. XX w. Jako metodę badań przyjęto wnioskowanie statystyczne w oparciu o dane liczbowe oraz interpretację graficzną otrzymanych wyników. Szczegółowej analizie poddano stan infrastruktury uzdrowisk oraz zmiany w jej wykorzystaniu. Następnie zilustrowano panujące trendy zaobserwowane w ostatnich latach w zdrojowiskach polskich ${ }^{1}$. Wykorzystane w badaniach dane pozyskano z Głównego Urzędu Statystycznego, Ministerstwa Zdrowia oraz z opracowania Lecznictwo uzdrowiskowe w Polsce w latach 2000-2010.

\section{Uzdrowiska w Polsce}

Według prawodawstwa polskiego (Ustawa z dnia 28 lipca 2005 r. o lecznictwie uzdrowiskowym, uzdrowiskach i obszarach ochrony uzdrowiskowej oraz o gminach uzdrowiskowych. Dz. U. z 2012 r., poz. 651) uzdrowiskiem może zostać obszar, na terenie którego prowadzone jest lecznictwo uzdrowiskowe. Obszar ten zostaje wydzielony w celu wykorzystania i ochrony znajdujących się na jego terenie naturalnych surowców leczniczych. Uznanie miejscowości za uzdrowisko następuje po opracowaniu operatu uzdrowiskowego przez gminę, pozwalającego stwierdzić posiadanie określonych w ustawie cech, tj.: klimatu lokalnego o walorach zdrowotnych, unikalnych, naturalnych złóż surowców uzdrowiskowych, zakładów opieki zdrowotnej udzielających świadczeń z zakresu lecznictwa uzdrowiskowego przez wysoko wykwalifikowane kadry medyczne, obiektów szpitalnych i sanatoryjnych z pełnym zapleczem o wysokim standardzie, urządzeń przeznaczonych do korzystania z uzdrowiskowych zasobów naturalnych, wymagań sprecyzowanych w przepisach prawa o ochronie i kształtowaniu środowiska, odpowiedniego obszaru pozwalającego na wyodrębnienie stref ochrony uzdrowiskowej ${ }^{2}$ oraz pełnej infrastruktury technicznej.

Ze względu na położenie geograficzne rozróżnia się: uzdrowiska nizinne (do 200 m n.p.m.), nadmorskie (położone w odległości nie większej niż $3 \mathrm{~km}$ od brzegu morza), podgórskie (od 200 do 400 m n.p.m.) oraz górskie (zlokalizowane na wysokości od 400 do 800 m n.p.m.).

\footnotetext{
${ }^{1} \mathrm{O}$ przemianach własnościowych i organizacyjno-funkcjonalnych w rodzimych zdrojowiskach pisali m.in. D. Reśko, Potencjał uzdrowisk polskich w rozwoju regionalnym. W: T. Kudłacz (red.), Rozwój regionalny w Polsce w świetle wyzwań XXI w., Studia KPZK, t. CXXXI, Warszawa 2010; D. Reśko, Problematyka funkcjonowania sektora uzdrowiskowego w Polsce - wybrane aspekty. W: Transgraniczna turystyka ekologiczna jako szansa rozwoju regionu. „Zeszyty Naukowe”, nr 1, Nowy Sącz 2010; K. Prętki, Podstawy prawne funkcjonowania lecznictwa uzdrowiskowego w systemie ochrony zdrowia $w$ Polsce $w$ latach 1918-2005. W: B. Płonka-Syroka, A. Syroka (red.), Historia polskiej kultury uzdrowiskowej. Wrocław 2012. Zagadnienie uzdrowiskowych produktów turystycznych w pierwszej kolejności podjęła D. Dryglas, Ksztattowanie produktu turystycznego uzdrowisk w Polsce. Kraków 2006.

${ }^{2}$ Strefa A z udziałem terenów zieleni nie mniejszym niż 65\%. Strefa B z udziałem terenów biologicznie czynnych nie mniejszym niż $50 \%$ oraz strefa $\mathrm{C}$ z udziałem terenów biologicznie czynnych nie mniejszym niż $45 \%$.
} 
Ze względu na występujące naturalnie surowce lecznicze wyszczególniono: uzdrowiska posiadające wody lecznicze, uzdrowiska borowinowe - oparte na leczeniu borowiną - oraz uzdrowiska mieszane - posiadające wody lecznicze i borowinę.

Współcześnie w Polsce statusem uzdrowiska dysponują 44 gminy oraz Kopalnia Soli w Wieliczce, działająca jako sanatorium uzdrowiskowe w urządzonym podziemnym wyrobisku górniczym³ (ryc. 1). Od 2001 r. do działalności leczniczej uprawniony jest także Latoszyn w województwie podkarpackim, który uzyskał status obszaru ochrony uzdrowiskowej, co oznacza, że ma przywileje i obowiązki takie same, jak uzdrowisko, bez konieczności dysponowania własnym sanatorium. W 2013 r. ochroną uzdrowiskową objęto również Skierniewice, w których odkryto solankę, Rogoźno koło Zgierza oraz Frombork i Miłomłyn nieopodal Ostródy. W kolejce oczekują m.in.: Czarny Dunajec, Łagów, Trzebnica, Łeba i Lidzbark Warmiński. Uzyskanie statusu miejscowości uzdrowiskowej pozwala na pobierania opłaty uzdrowiskowej od osób przebywających na obszarze uzdrowiska. Ponadto gminy otrzymują dotację z budżetu państwa w wysokości równej wpływom z tytułu tejże opłaty w poprzednim roku kalendarzowym, w celu zapewnienia właściwych standardów uzdrowiskowych. Atrakcyjnie położone i dobrze prosperujące uzdrowisko może zatem dostarczyć samorządowi wielomilionowych wpływów. Innym wymiernym zyskiem dla gminy jest reklama oraz napływ turystów przez cały rok. Gminy, które uzyskają status obszaru ochrony uzdrowiskowej, ustawodawca również wyposażył w prawo do pobierania opłaty miejscowej za każdy dzień pobytu w celach turystycznych, szkoleniowych czy wypoczynkowych.

Ryc. 1. Przestrzenne rozmieszczenie uzdrowisk w Polsce

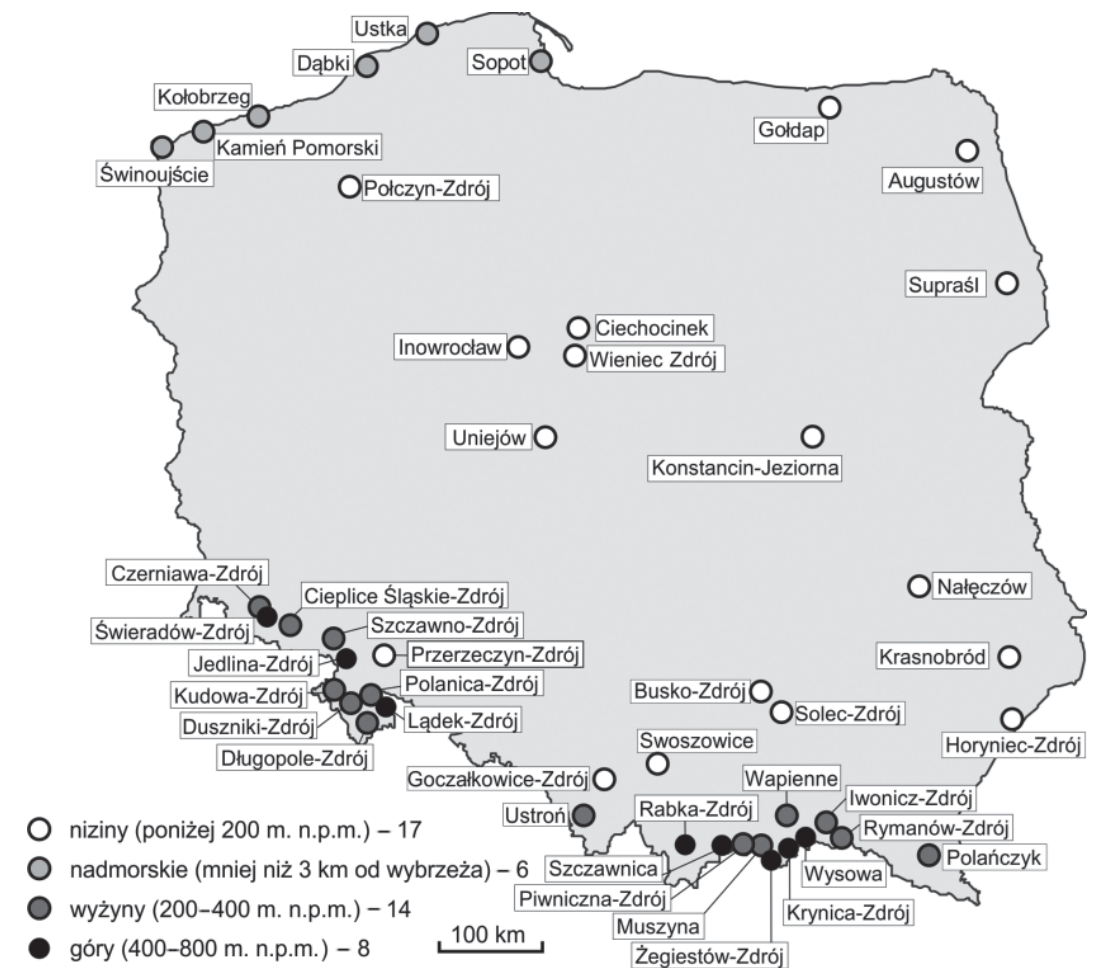

Źródło: opracowano na podstawie wykazu Ministerstwa Zdrowia RP.

${ }_{3}^{3}$ Działalność lecznicza w uzdrowisku Kopalnia Soli w Wieliczce polegająca na wykorzystaniu unikalnego mikroklimatu, przejawiającego się znacznym nasyceniem powietrznego aerosolu chlorkiem sodu, realizowana jest w znajdujących się $135 \mathrm{~m}$ pod ziemią wyrobiskach górniczych. Oprócz tradycyjnego, 21-dniowego turnusu uzdrowiskowego kuracjusze mogą skorzystać z pobytów dziennych oraz programów: Trzy godziny dla zdrowia, Dzień dla zdrowia, Zdrowy sen. Uprawnienia do prowadzenia lecznictwa uzdrowiskowego Kopalna Soli „Wieliczka” S.A. otrzymała w 2011 r. 
Jednakże wraz z prawami przysługującymi uzdrowiskom nałożono na nie również obowiązki, które regulowane są m.in. przez Rozporzadzenie Ministra Zdrowia z dnia 2 kwietnia 2012 r. w sprawie określenia wymagań, jakim powinny odpowiadać zakłady i urządzenia lecznictwa uzdrowiskowego (Dz. U. z 2012 r., poz. 452) Powinnością gminy uzdrowiskowej jest zachowanie wskaźników terenów zielonych i obszarów biologicznie czynnych. Prowadzi to do zakazu lokalizowania w strefach uzdrowiskowych obiektów mogących znacząco oddziaływać na środowisko, np. inwestycji komunikacyjnych i wielkopowierzchniowych. Ograniczenia te są związane z integralnością lecznictwa uzdrowiskowego z państwowym systemem ochrony zdrowia. Wspomniana forma leczenia prowadzona jest w wyspecjalizowanych zakładach zlokalizowanych w uzdrowiskach przy wykorzystaniu właściwych urządzeń, umożliwiających zastosowanie naturalnych surowców leczniczych oraz właściwości zdrowotnych klimatu. Pacjent w ramach leczenia uzdrowiskowego może skorzystać z następujących zakładów lecznictwa uzdrowiskowego: szpitala uzdrowiskowego, sanatorium uzdrowiskowego, zakładu przyrodoleczniczego, szpitala w podziemnych wyrobiskach górniczych oraz przychodni uzdrowiskowej ${ }^{4}$. Leczenie w uzdrowisku przyjmowane jest za kontynuację leczenia szpitalnego pacjentów bądź rehabilitację. Wśród najważniejszych zasad charakteryzujących polski system lecznictwa zdrojowiskowego Ryszard Florków wyróżnił sprecyzowanie dla każdego zdrojowiska profilu leczniczego, zestawienie wskazań i przeciwwskazań w odbywaniu kuracji w danym ośrodku oraz przestrzeganie przez kuracjuszy zasad reżimu leczniczego (Florków, 1994). Badająca zagadnienie lecznictwa uzdrowiskowego jako elementu aktywnego wypoczynku i zdrowego stylu życia Agnieszka Chojecka (por. 2011) dowodzi, że polskie społeczeństwo przybywające do wód można podzielić na dwie grupy: regularnych gości, rozmiłowanych w kulturze zdrojowiskowej, oraz osoby wybierające się tam po raz pierwszy i chętnie powracające. Kuracjusza na turnus może skierować NFZ lub może on występować w charakterze pełnopłatnego klienta komercyjnego.

W nawiązaniu do modelu działalności przedsiębiorstwa w strukturze regionu Zbigniew Zioło (1999) dokonał próby skonstruowania modelu funkcjonowania uzdrowisk w Polsce (ryc. 2). Główną determinantą rozwoju uzdrowiska jest przestrzeń przyrodnicza i związane z nią zasoby surowców leczniczych. Drugim ważnym elementem niezbędnym do funkcjonowania uzdrowiska jest infrastruktura lecznicza wraz z całym jej zapleczem i pracownikami. Wartym podkreślenia czynnikiem jest także przestrzeń kulturowa uzdrowiska, na którą składają się zarówno elementy kultury materialnej, jak i duchowej. Ta wewnętrzna sfera zdrojowiska wykorzystywana jest do kreowania usług medycznych, stanowiących dotychczas główny cel działalności uzdrowiska, oraz usług spa i wellnes wraz ze świadczeniami pozamedycznymi, np. noclegami, wyżywieniem, transportem, rozrywką. W zależności od ustaleń prawnych, nakładających na zdrojowiska obowiązek przestrzegania ustalonych norm oraz w odniesieniu do uwarunkowań sprzężonych z prawami rynku, struktura oferowanych usług będzie się zmieniać. Współcześnie najważniejszymi czynnikami wpływającymi na zmiany w działalności uzdrowisk w wymiarze makroekonomicznym są: postępujący proces starzenia się społeczeństwa, rozwój medycyny, zróżnicowanie w strukturze chorób, wzrost mobilności społeczeństwa, kłopoty z finansowaniem państwowych zakładów przyrodoleczniczych, rosnące zainteresowanie społeczeństwa zdrowym stylem życia, stan gospodarki wpływający na zamożność obywateli oraz przemiany polityczne na świecie, oddziałujące m.in. na możliwość podróży międzynarodowych. Obecnie zauważalny

\footnotetext{
${ }^{4}$ Uzdrowiskowe leczenie szpitalne oraz sanatoryjne osób dorosłych wynosi 21 dni (odpowiednio 27 i 21 dni w przypadku dzieci), leczenie ambulatoryjne od 6 do 18 dni zabiegowych, zaś uzdrowiskowa rehabilitacja w szpitalu uzdrowiskowym - 28 dni.
} 
jest w Polsce niewątpliwy rozwój infrastruktury uzdrowiskowej, zwłaszcza tej związanej z usługami pozamedycznymi oraz spa i wellness. Postępujący rozwój medycyny wpływa zaś na skrócenie okresu leczenia, oddziałując na wykorzystanie bazy zabiegowej. Równocześnie wzrasta udział ludzi młodych korzystających z usług zdrojowiskowych w ramach profilaktyki zdrowotnej. W przekonaniu Krzysztofa Prętki (2012) - nie biorąc pod uwagę zmieniających się realiów ustrojowych zachodzących w Polsce od roku 1918 r. - najważniejsze znaczenie dla charakteru lecznictwa uzdrowiskowego miało Ministerstwo Zdrowia.

Ryc. 2. Model funkcjonowania uzdrowisk

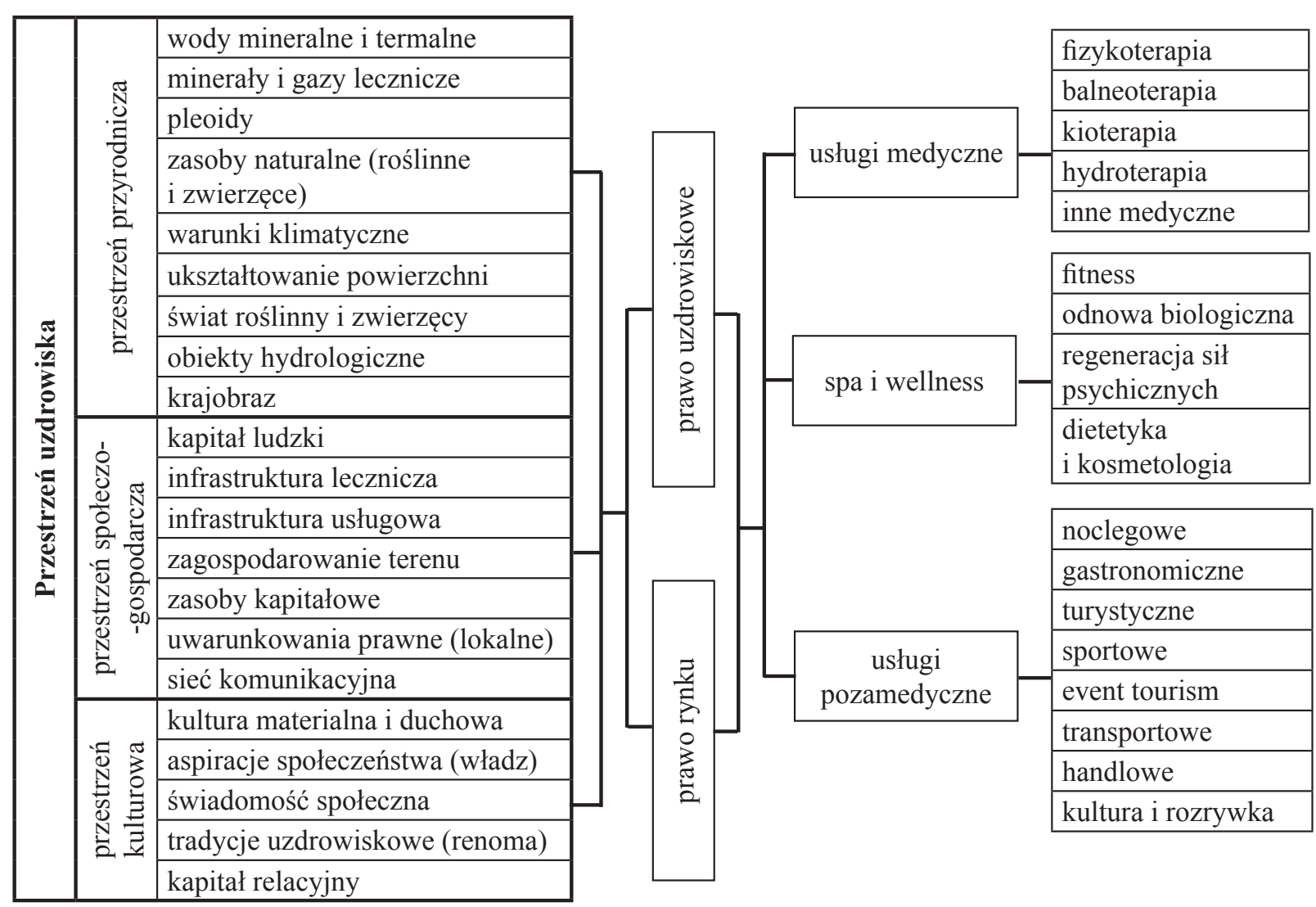

Źródło: opracowanie własne.

\section{Infrastruktura sanatoryjna w Polsce}

W 1995 r. w Polsce działało 250 sanatoriów $^{5}$ i szpitali uzdrowiskowych ${ }^{6}$. Następnie do 2005 r. nastąpił spadek liczby obiektów uzdrowiskowych do 221 (ryc. 3). Głównie było to spowodowane upadkiem obiektów sanatoryjnych będących częścią dużych zakładów przemysłowych

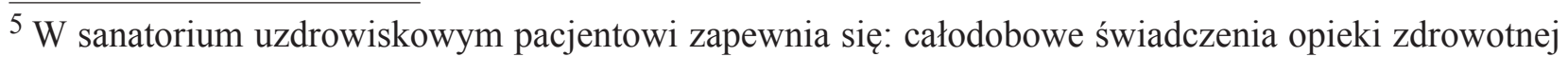
w warunkach stacjonarnych, opiekę lekarską i całodobową opiekę pielęgniarską, przewidziane programem leczenia zabiegi, świadczenia profilaktyczne oraz edukację zdrowotną. Ponadto w szpitalu uzdrowiskowym przewidziane jest korzystanie z naturalnych surowców leczniczych oraz urządzeń lecznictwa uzdrowiskowego.

${ }^{6} \mathrm{~W}$ szpitalu uzdrowiskowym pacjentowi zapewnia się: całodobowe świadczenia opieki zdrowotnej w warunkach stacjonarnych, całodobową opiekę lekarską i pielęgniarską, przewidziane programem leczenia zabiegi, korzystanie z naturalnych surowców leczniczych i urządzeń lecznictwa uzdrowiskowego oraz edukację zdrowotną.
} 
oraz trudnościami w finansowaniu leczenia przez państwo. Również w tym samym okresie zmniejszyła się liczba kuracjuszy. W okresie 1995- 2003 liczba osobodni zmalała o $1 \mathrm{mln}$. Od 2008 r. można zauważyć obecność tendencji wzrostowej zarówno w liczbie obiektów sanatoryjnych (wzrost do 259), jak i pobytu kuracjuszy o ponad 2,5 mln osobodni.

Ryc. 3. Zmiany w wykorzystaniu infrastruktury sanatoriów i szpitali uzdrowiskowych w Polsce w latach 1995-2013
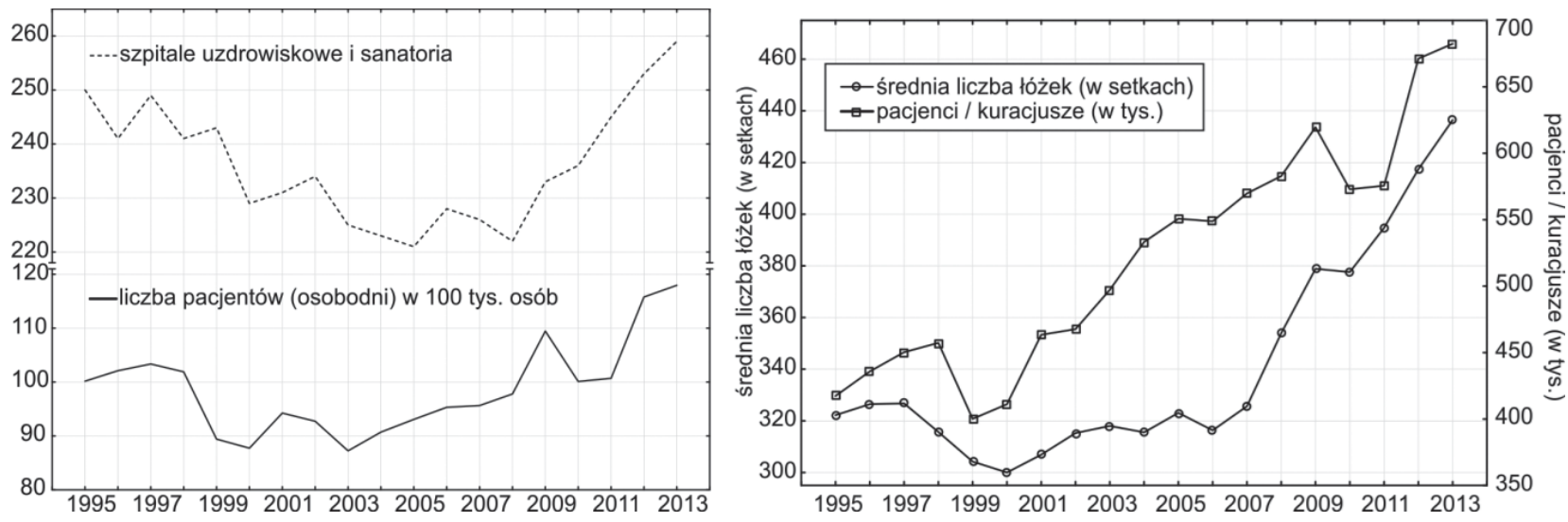

Źródło: opracowanie własne na podstawie BDL GUS oraz sprawozdania Lecznictwo uzdrowiskowe w Polsce w latach 2000-2010 Ministerstwa Zdrowia.

Pomimo spadku liczby ośrodków uzdrowiskowych w analizowanym okresie, poza latami 1998-2000 oraz 2009-2012, nastąpił wzrost liczby kuracjuszy. Świadczy to o rosnącym zainteresowaniu usługami uzdrowiskowymi przy jednoczesnym skróceniu długości pobytu. Równocześnie od 2008 r. nastąpiła widoczna tendencja wzrostu wielkości obiektów sanatoryjnych o prawie 10 tys. łóżek.

Można zatem wnioskować, że po okresie upadku obiektów państwowych i branżowych, w wyniku wzrostu zapotrzebowania na usługi sanatoryjne oraz wskutek procesu prywatyzacji uzdrowisk, nastąpił rozwój infrastruktury sanatoryjnej w Polsce (ryc. 4). Obserwowany wzrost liczby obiektów sanatoryjnych nie był jednakowy w całym kraju. Spośród czołówki uzdrowisk największą bazę sanatoryjną w 2014 r. miały Ciechocinek (25 sanatoriów i szpitali) oraz Kołobrzeg (21). Jednakże w przypadku Ciechocinka w okresie 1995-2014 stwierdzono wzrost ośrodków leczniczych, zaś w Kołobrzegu nastąpił ich ubytek. Również wyraźny spadek zanotowała Krynica-Zdrój.

Likwidacja obiektów pozostaje charakterystyczna przede wszystkim dla uzdrowisk górskich ze szczawami, np. Krynicy-Zdroju, Szczawnicy, Muszyny, Polanicy-Zdroju, Kudowy-Zdroju czy Iwonicza-Zdroju. Są to kurorty, które w 1995 r. miały najwięcej sanatoriów (ryc. 5). W badanym okresie wzrost odnotowały zatem głównie mniejsze ośrodki w centralnej Polsce i nad morzem: Ciechocinek, Nałęczów, Wieniec Zdrój, Świnoujście, Sopot. Obserwowana zależność związana jest z postępem w medycynie, pozwalającym na leczenie wielu chorób - np. kamicy nerkowej - w którym wykorzystuje się wody szczawiowe. Rozwój kurortów na terenach nizinnych wiąże się z występowaniem wód siarkowych skutecznych przy leczeniu schorzeń narządu ruchu - reumatycznych i będących następstwem urazów, a także w dolegliwościach skórnych (alergiach). Natomiast uzdrowiska nadmorskie, poza ofertą uzdrowiskową, stanowią atrakcyjne miejsca turystyczne. Rozwój obserwujemy również w miejscowościach z wodami geotermalnymi, np. w Ustroniu. Na terenie zdrojowisk, które utraciły część klientów, pojawiają się inne specjalistyczne usługi medyczne, czego przykładem może być Specjalistyczne Centrum Medyczne w Polanicy-Zdroju, będące ważnym ośrodkiem chirurgii plastycznej w Polsce. 
Ryc. 4. Liczba sanatoriów i szpitali uzdrowiskowych w Polsce w latach 1995-2014

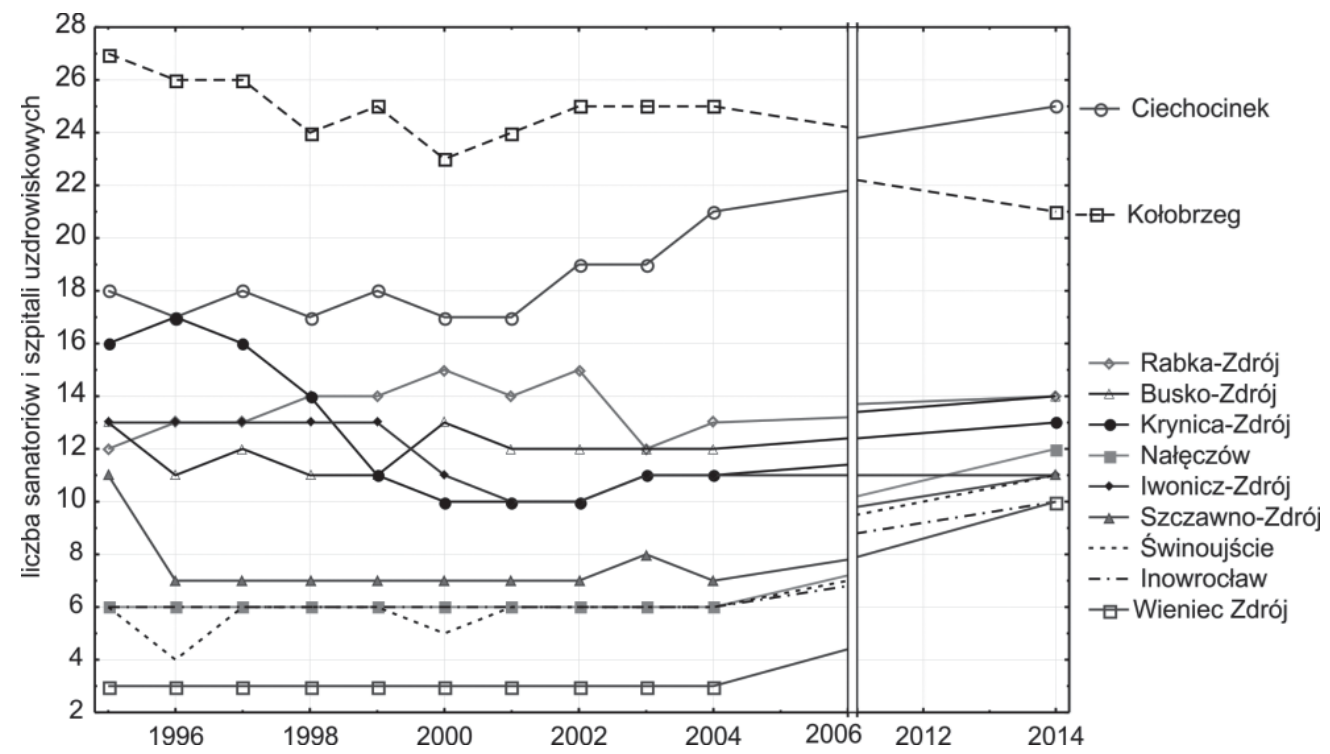

Źródło: opracowanie własne na podstawie BDL GUS oraz sprawozdania Lecznictwo uzdrowiskowe w Polsce w latach 2000-2010 Ministerstwa Zdrowia.

Ryc. 5. Zmiana liczby sanatoriów i szpitali uzdrowiskowych w Polsce w latach 1995-2014

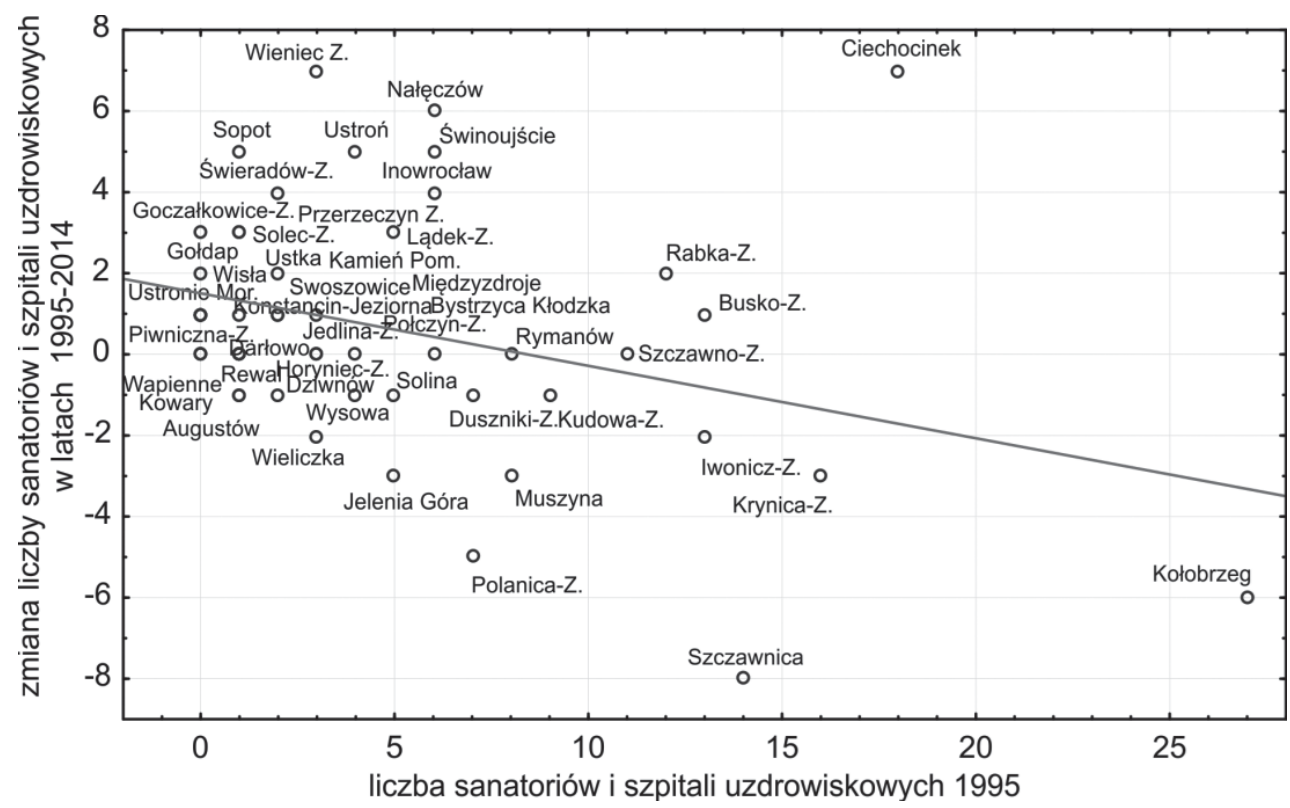

Źródło: opracowanie własne na podstawie BDL GUS oraz sprawozdania Lecznictwo uzdrowiskowe w Polsce w latach 2000-2010 Ministerstwa Zdrowia.

Pod względem zwiększenia liczby łóżek w obiektach sanatoryjnych w Polsce pierwsze miejsce zajmuje Kołobrzeg, gdzie nastąpił wzrost o 2 tys. łóżek, oraz Ciechocinek ze wzrostem o 1 tys. (ryc. 6). Następnymi w kolejności miejscowościami kuracyjnymi pod względem liczby miejsc noclegowych w obiektach sanatoryjnych są Busko-Zdrój, Krynica-Zdrój i Ustron. Tak wysoki wskaźnik wzrostu łóżek w Kołobrzegu związany jest nie tylko z nadmorskim położeniem i renomą uzdrowiska, lecz także z bliskością niemieckiej granicy, co wpływa na dostrzegalny udział kuracjuszy zagranicznych. Również w Ustroniu można zauważyć wzrost kuracjuszy z Niemiec. Jednakże od początku badanego okresu po pierwsze lata XXI w. w większości dużych uzdrowisk odnotowano spadek liczby łóżek, co wpłynęło na niski wskaźnik wzrostu łóżek w stosunku do potencjału noclegowego. Szczególnie jest to widoczne w Ciechocinku i Kołobrzegu. 
Największy wzrost odnotowały zatem małe uzdrowiska: Sopot, Goczałkowice-Zdrój czy Dąbki. Tym samym można dowieść ujemnej zależności pomiędzy wielkością bazy noclegowej a jej średniorocznym wzrostem (ryc. 6 i 7). Natomiast odnosząc się do tendencji w zmianie liczby łóżek wykreślonej linią regresji, największy przyrost odnotowały Kołobrzeg (ok. 150 łóżek rocznie), Dąbki i Ustroń (ok. 60 łóżek na rok) oraz Ciechocinek (ok. 40 łóżek na rok).

Ryc. 6. Liczba łóżek w szpitalach i sanatoriach uzdrowiskowych w latach 1995-2014

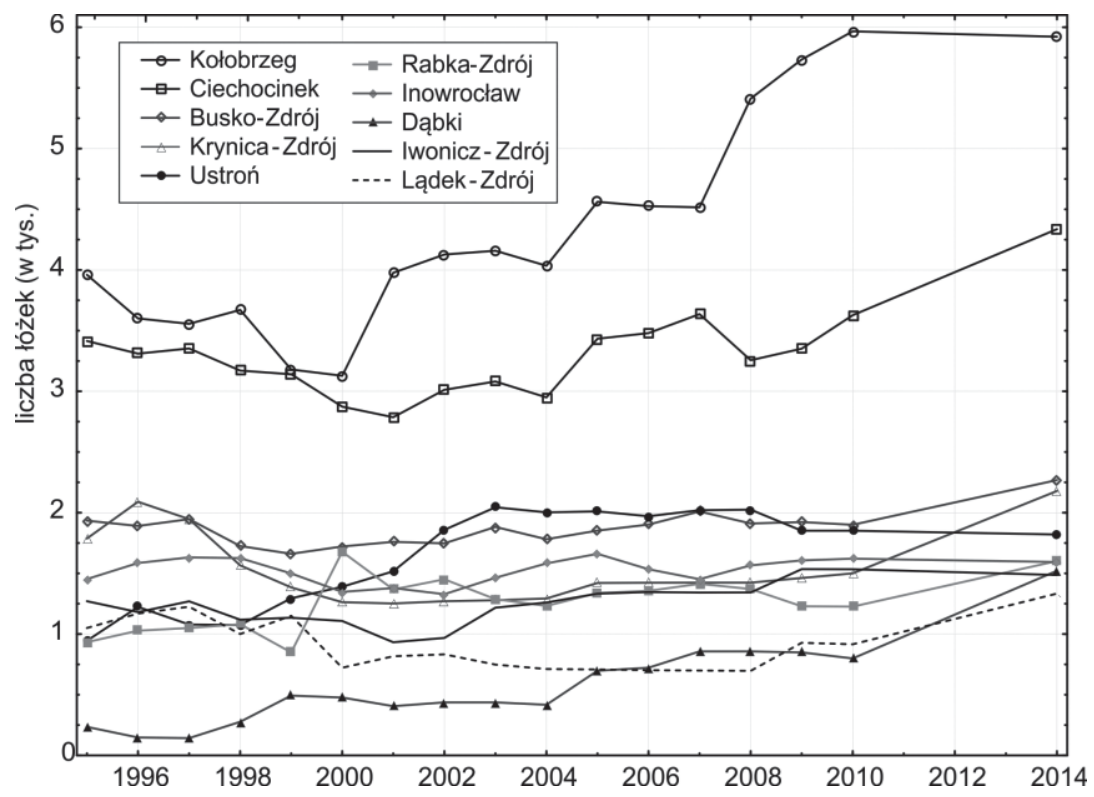

Źródło: opracowanie własne na podstawie BDL GUS oraz sprawozdania Lecznictwo uzdrowiskowe w Polsce w latach 2000-2010 Ministerstwa Zdrowia.

Ryc. 7. Zmiany liczby łóżek w szpitalach i sanatoriach uzdrowiskowych w latach 1995-2014

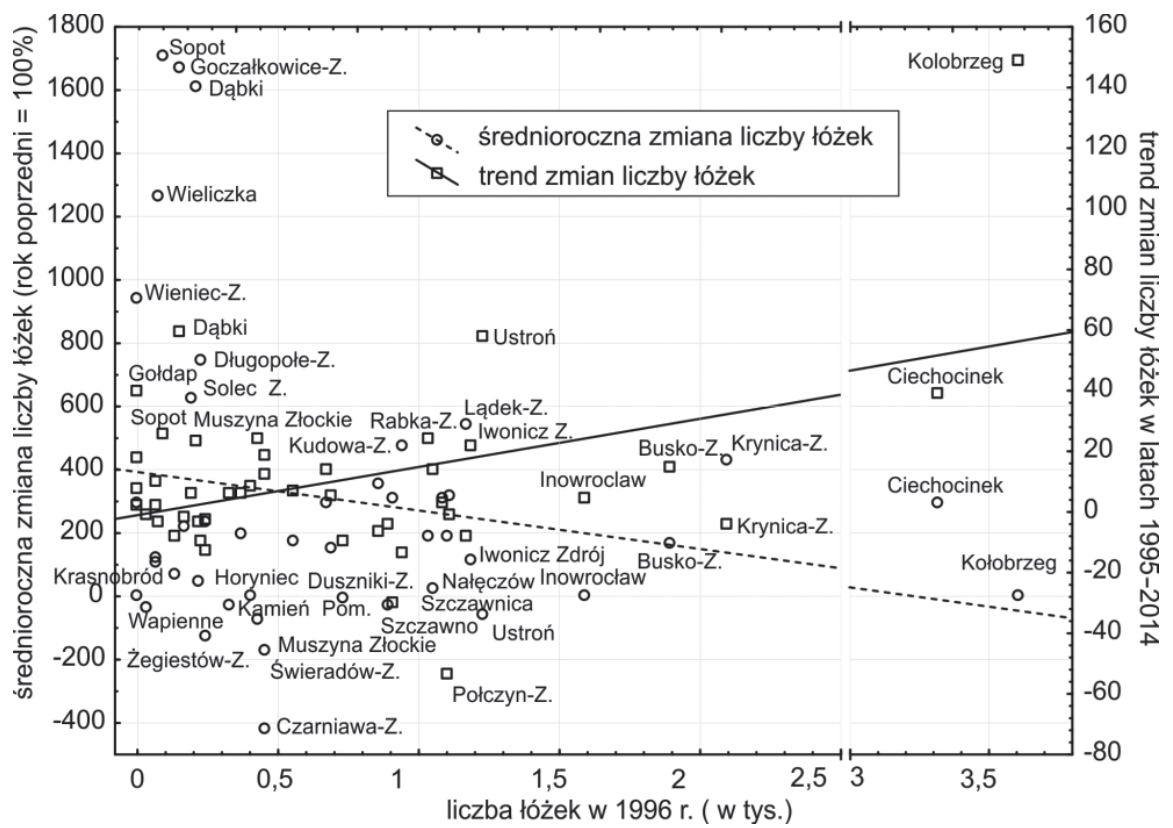

Źródło: opracowanie własne na podstawie BDL GUS oraz sprawozdania Lecznictwo uzdrowiskowe w Polsce w latach 2000-2010 Ministerstwa Zdrowia. 


\section{Frekwencja w obiektach sanatoryjnych uzdrowisk Polski}

W badanym okresie następowała również zmiana frekwencji kuracjuszy. W latach 1995-2010 zaobserwowano dwa wyraźne spadki ich liczby. Pierwszy miał miejsce pod koniec lat 90. XX. w. i trwał do początku XXI w. Podczas gdy drugi związany był ze światowym kryzysem finansowym z 2008 r. Ogólnie w badanym okresie liczba kuracjuszy w uzdrowiskach w Polsce wzrosła o 200 tys., przy czym do początku obecnego wieku zauważalna była tendencja wzrostu zamienności frekwencji kuracjuszy w poszczególnych uzdrowiskach, która następnie została wyrównana. Spośród rodzimych uzdrowisk największą liczbą kuracjuszy odznaczają się Kołobrzeg (ok. 104 tys.) i Ciechocinek (61 tys.). Następnymi w kolejności są Busko-Zdrój (34 tys.) oraz Krynica-Zdrój i Inowrocław (26 tys.). Jak można zauważyć na ryc. 8, wzrost liczby kuracjuszy nie był ciągły. Dlatego analizując średnioroczną zmianę liczby kuracjuszy w stosunku do roku poprzedniego, największy wzrost (średnio ponad 10\%) odnotowały Goczałkowice-Zdrój, Darłowo, Gołdap i Sopot oraz Piwniczna-Zdrój. Są to małe i średnie uzdrowiska, do których przybywało rocznie średnio ok. 0,5 tys. kuracjuszy. Natomiast najniższy średni wzrost w stosunku do lat poprzednich charakteryzował Szczawnicę, Nałęczów, KrynicęZdrój i Bystrzycę Kłodzką.

Odnosząc się do tendencji zmian, największą z nich stwierdzono w Kołobrzegu (średni roczny wzrost o 4,4 tys. kuracjuszy), Ciechocinku (1,7 tys.) i Darłowie (1,3 tys.). Następnymi w kolejności były Busko-Zdrój i Krynica-Zdrój z ok. 1 tys. kuracjuszów rocznie, podczas gdy trend spadkowy odnotowała Rabka-Zdrój (ryc. 8 i 9). Przyczyn tych procesów jest wiele. Wiążą się one zarówno z kwestią położenia przygranicznego, jak i uwarunkowaniami kulturowo-historycznymi, czego dobrym przykładem pozostaje Kołobrzeg. Na liczbę klientów wpływa popularność zabiegów, np. zapotrzebowanie na zabiegi związane z układem ruchowym (Gołdap, Piwniczna-Zdrój), chorobami skóry czy otyłością (Ciechocinek). Duże znaczenie ma także specjalizacja ośrodka, np. rozwój usług krioterapii w Goczałkowicach-Zdroju. Na spadek liczby kuracjuszy wpłynęły ponadto przemiany własnościowe, np. w Szczawnicy, czy spadek leczenia uzdrowiskowego u dzieci, np. w Rabce-Zdroju.

Ryc. 8. Zmiana liczby kuracjuszy w uzdrowiskach w Polsce (A) oraz wybranych kurortach (B) latach 1995-2010
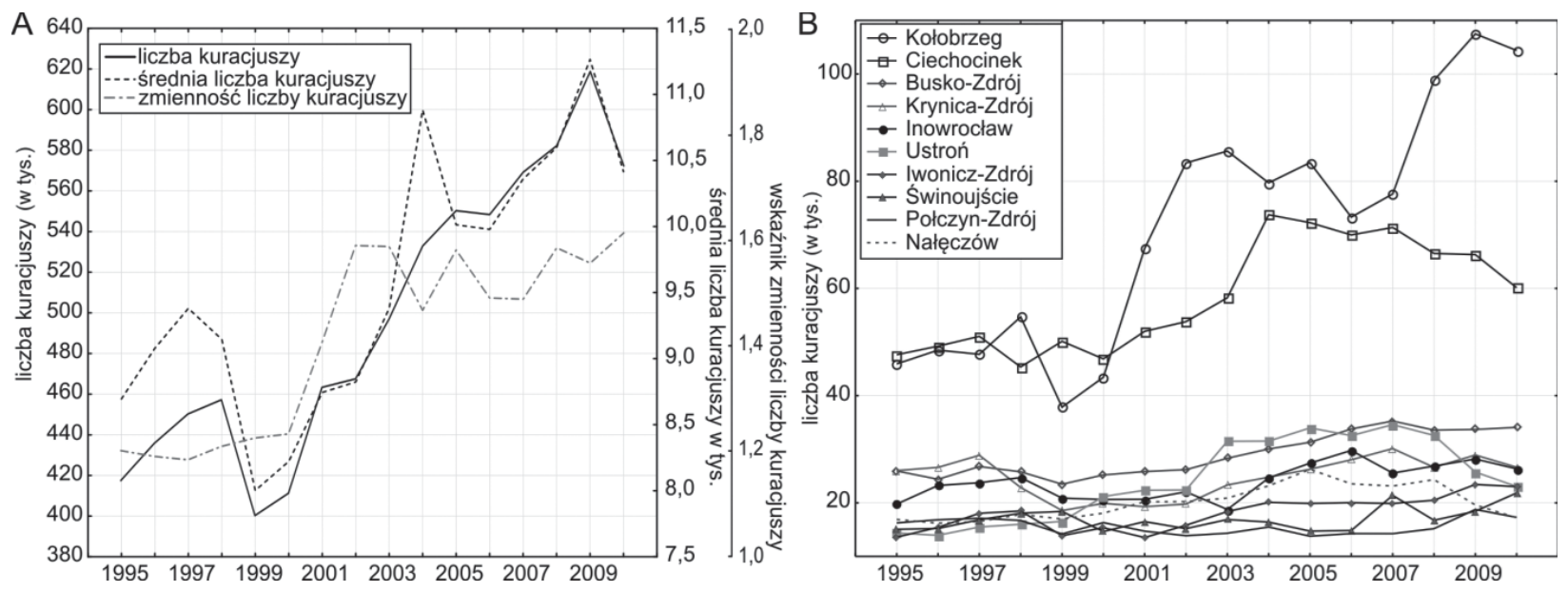

Źródło: opracowanie własne na podstawie BDL GUS oraz sprawozdania Lecznictwo uzdrowiskowe w Polsce w latach 2000-2010 Ministerstwa Zdrowia. 
Ryc. 9. Trend średniorocznej zmiany liczby kuracjuszy w uzdrowiskach Polski w latach 1995-2010

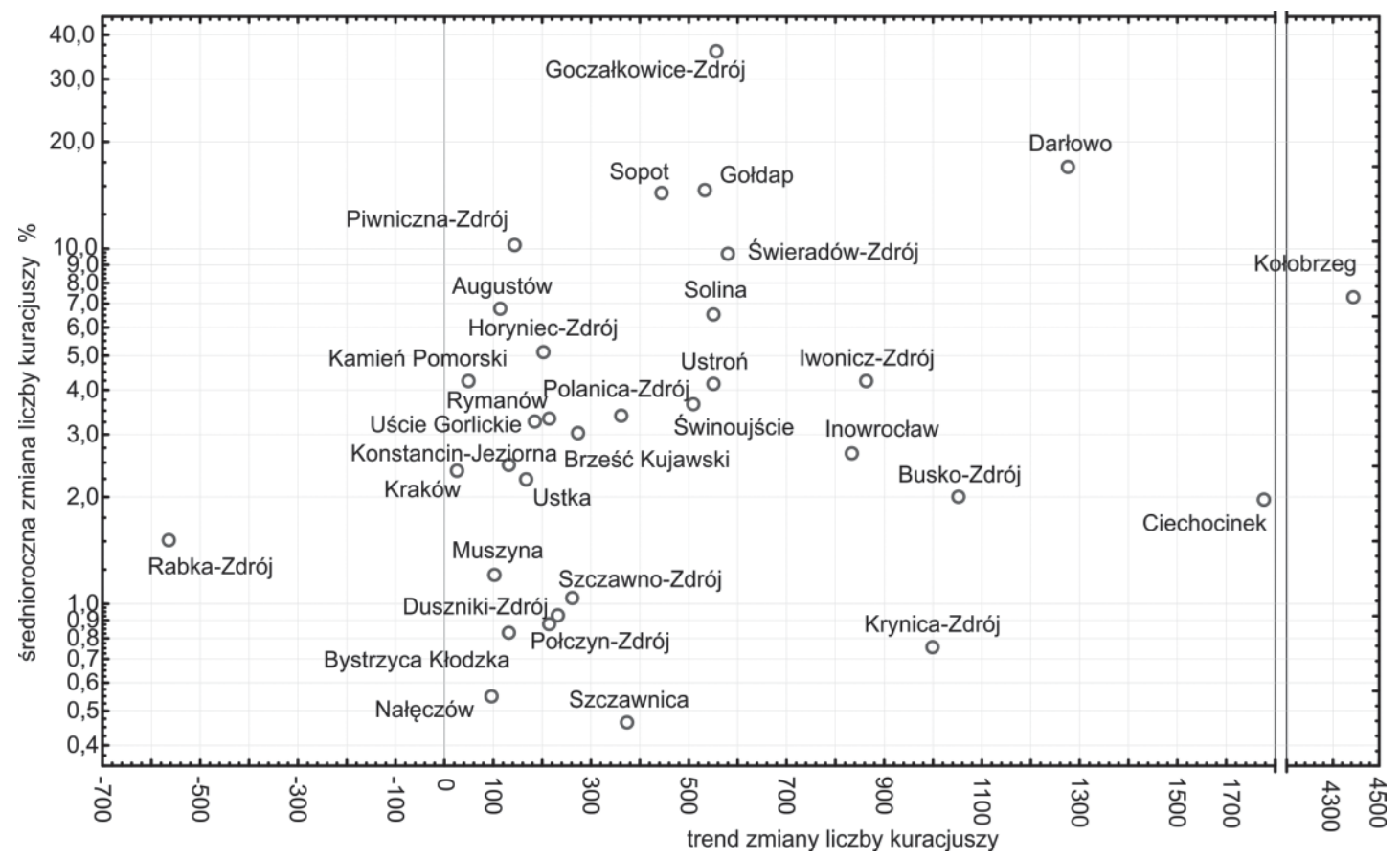

Źródło: opracowanie własne na podstawie BDL GUS oraz sprawozdania Lecznictwo uzdrowiskowe w Polsce w latach 2000-2010 Ministerstwa Zdrowia.

\section{Podsumowanie}

Reasumując, warto odnotować, że począwszy od połowy lat 90. XX w. w Polsce nastąpił wzrost liczby najpopularniejszego rodzaju placówek lecznictwa zdrojowiskowego - sanatoriów oraz szpitali uzdrowiskowych, co ilustruje omówiony w pracy przykład Ciechocinka i Kołobrzegu. Tendencja spadkowa charakteryzowała głównie ośrodki górskie i podgórskie: Krynicę-Zdrój, Szczawnicę, Muszynę czy Kudową-Zdrój. Przyjąwszy za kryterium wzrost liczby łóżek w obiektach sanatoryjnych, Kołobrzeg i Ciechocinek również zajęły dwa pierwsze miejsca. Należy zauważyć, że wysoki wskaźnik wzrostu łóżek w Kołobrzegu powodowany był nadmorskim położeniem kurortu, co dwojako wpływa na jego atrakcyjność. Stanowi wszakże popularne miejsce turystyczne dla Polaków, ale i kuracjuszy niemieckich. Na podstawie przeprowadzonych badań wykazano ujemną zależność pomiędzy wielkością bazy noclegowej a jej średniorocznym wzrostem, czego potwierdzeniem pozostają małe uzdrowiska: Sopot, Goczałkowice-Zdrój i Dąbki. Rosnące zainteresowanie usługami przyrodoleczniczymi przyniosło zauważalne zwiększenie liczby kuracjuszy przy jednoczesnym skróceniu długości pobytu. Trend wzrostowy utrzymuje się nadal, pomimo wciąż odczuwalnych negatywnych skutków światowego kryzysu finansowego. Dwa wyraźne spadki liczebności gości w okresie 1995-2010 były krótkotrwałe. Na popularyzację polskich wód bez wątpienia wpłynął dynamiczny rozwój młodej turystyki spa i wellness, będącej obecnie istotnym uzupełnieniem oferty uzdrowiskowej, a powszechnie wykorzystywanej w nowoczesnym hotelarstwie. Wzmiankowana forma hotelarstwa, oparta na naturalnych wodach leczniczych w wybranych kurortach uzdrowiskowych, coraz częściej zaczyna być produktem już nie tylko akcesoryjnym, lecz podstawowym (Kaleta, 2012). W połowie drugiej dekady XXI w. największą koncentracją 
kuracjuszy odznaczały się Kołobrzeg, Ciechocinek, Busko-Zdrój oraz Krynica-Zdrój pod względem liczby udzielonych noclegów oraz przestrzennego rozmieszczenia ruchu turystycznego będąca bezspornym liderem wśród miejscowości uzdrowiskowych województwa małopolskiego. Zasadne będzie zatem stwierdzenie, że w wyniku procesu transformacji systemowej w polskich zdrojowiskach w ostatnim ćwierćwieczu dokonały się zauważalne przemiany ilościowe oraz jakościowe, widoczne w infrastrukturze turystycznej i przybywających do wód kuracjuszach. Urzeczywistniła się tym samym wizja wielkiego propagatora polskich uzdrowisk i rodzimej balneologii prof. dr. Józefa Dietla (Dietl, 1857), trafnie prognozującego w połowie XIX w., że w przyszłości wody lecznicze staną się istotnym elementem krajowej gospodarki.

\section{Literatura \\ References}

Chojecka, A. (2011). Lecznictwo uzdrowiskowe elementem kształtującym aktywny wypoczynek i zdrowy styl życia człowieka. W: B. Płonka-Syroka, A. Syroka (red.). Kultura uzdrowiskowa w Europie, t. II. Historia polskiej kultury uzdrowiskowej. Wrocław, 287-295.

Dietl, J. (1858). Uwagi nad zdrojowiskami krajowemi ze względu na ich skuteczność, zastosowanie i urzadzenie. cz. I, Kraków, 160.

Florków, R. (1994). Istota, znaczenie i formy leczenia uzdrowiskowego oraz ogólne przeciwwskazania bezwzględne. W: F. Kiryk (red.), Krynica, Kraków, 71.

Golba, J. (2001). Rozwój infrastruktury uzdrowiskowej oraz okołouzdrowiskowej jako podstawa rozwoju miejscowości uzdrowiskowych. W: Turystyka i sport w działalności rządu, samorzadów terytorialnych i organizacji pozarządowych. Materiały III Forum Turystyki i Sportu Samorzadów Terytorialnych RP, Kraków, 18-19 maja 2001 r., 60-68.

Lisowska, B. (2014) W Polsce powstaną nowe uzdrowiska. Ale kuracjusze nie będą mogli z nich korzystać. Pozyskano z: http://serwisy.gazetaprawna.pl/samorzad/artykuly/778802,w-polscepowstana-nowe-uzdrowiska-ale-kuracjusze-nie-beda-mogli-z-nich-korzystac.html

Kaleta, A. (2012). Hotelarstwo Spa i Wellness jako rozwojowy produkt przemysłu czasu wolnego wybrane aspekty. Zarzadzanie i Finanse, 1, 361-371.

Prętek, K. (2011). Podstawy prawne funkcjonowania lecznictwa uzdrowiskowego w systemie ochrony zdrowia w Polsce w latach 1918-2005. W: B. Płonka-Syroka, A. Syroka (red.), Kultura uzdrowiskowa w Europie, t. II. Historia polskiej kultury uzdrowiskowej. Wrocław, 187.

Rachwał, T. (2006). Restrukturyzacja technologiczna przedsiębiorstw przemysłowych Polski PołudniowoWschodniej jako czynnik podnoszenia ich konkurencyjności na rynku międzynarodowym. Prace Komisji Geografii Przemystu Polskiego Towarzystwa Geograficznego, 8, 192-203.

Wołowiec, T. (2002). Problemy finansowo-prawne funkcjonowania rozwoju polskich uzdrowisk. Folia Turistica, 12, 89-99.

Wołowiec, T. (2003). Sposoby rewitalizacji polskich uzdrowisk. Ustawa o gminach uzdrowiskowych i inne formy aktywizacji społeczno-gospodarczej. Folia Turistica, 14, 5-25.

Zioło, Z. (1999). Model funkcjonowania przestrzeni geograficznej jako próba integracji badań geograficznych. W: A. Lisowski (red.), Geografia na przełomie wieków - jedność w różnorodności. Warszawa: Wydział Geografii i Studiów Regionalnych Uniwersytetu Warszawskiego, 122-131.

Zioło, Z. (2011). Funkcjonowanie przedsiębiorstwa w strukturze regionu - zarys modelu. Nierówności spoleczne a wzrost gospodarczy. Uwarunkowania sprawnego działania w przedsiębiorstwie i regionie, 20, Rzeszów: Wydawnictwo Uniwersytetu Rzeszowskiego, 26-46. 
Sławomir Dorocki, dr. Absolwent studiów z zakresu geografii społeczno-ekonomicznej, doktor nauk humanistycznych w dyscyplinie historia (Instytut Europeistyki - Uniwersytet Jagielloński). Adiunkt w Instytucie Geografii Uniwersytetu Pedagogicznego im. Komisji Edukacji Narodowej w Krakowie. Zainteresowania badawcze autora skupiają się wokół problematyki regionów i procesów regionalizacji społeczno-gospodarczej, ze szczególnym uwzględnieniem zróżnicowania przestrzeni europejskiej oraz procesów integracji europejskiej i uwarunkowań historycznych.

Sławomir Dorocki, graduated from Pedagogical University of Cracow MS degree in geography, $\mathrm{PhD}$ in history (Institute of European Studies of the Jagiellonian University). Adiunkt (assoc. professor) at Pedagogical University of Cracow, Institute of Geography. His research interests are tied with regional problems and processes of socio-economic regionalization, with particular emphasis on the diversity of Europe, processes of European integration and historical conditions.

Adres/Address: Uniwersytet Pedagogiczny im. Komisji Edukacji Narodowej w Krakowie Instytut Geografii Zakład Przedsiębiorczości i Gospodarki Przestrzennej ul. Podchorążych 2 30-084 Kraków, Polska e-mail: sdorocki@up.krakow.pl

Pawel Brzegowy, mgr. Absolwent Instytutu Nauk Politycznych i Stosunków Międzynarodowych Uniwersytetu Jagiellońskiego, doktorant w Instytucie Geografii Uniwersytetu Pedagogicznego im. Komisji Edukacji Narodowej w Krakowie. Główne zainteresowania badawcze autora dotyczą galicyjskiego przemysłu uzdrowiskowego oraz geografii społecznej i gospodarczej departamentów zamorskich Francji.

Pawel Brzegowy, graduate of the Institute of Political Studies and International Relations at the Jagiellonian University, doctoral student at the Institute of Geography at the Pedagogical University of Cracow named after the National Education Commission. Main research interests focused on social and economic geography of extra-European France departments and communities.

Adres/Address: $\quad$ Uniwersytet Pedagogiczny im. Komisji Edukacji Narodowej w Krakowie Instytut Geografii

ul. Podchorążych 2

30-084 Kraków, Polska

e-mail: pawel.brzegowy@uj.edu.pl 